IZA DP No. 7275

The Transformation of Hunger Revisited

Ian Gazeley

Andrew Newell

Mintewab Bezabih

March 2013

Forschungsinstitut

zur Zukunft der Arbeit Institute for the Study

of Labor 


\title{
The Transformation of Hunger Revisited
}

\author{
Ian Gazeley \\ University of Sussex \\ Andrew Newell \\ University of Sussex \\ and IZA
}

\author{
Mintewab Bezabih \\ London School of Economics
}

\section{Discussion Paper No. 7275 \\ March 2013}

\author{
IZA \\ P.O. Box 7240 \\ 53072 Bonn \\ Germany \\ Phone: +49-228-3894-0 \\ Fax: +49-228-3894-180 \\ E-mail: iza@iza.org
}

\begin{abstract}
Any opinions expressed here are those of the author(s) and not those of IZA. Research published in this series may include views on policy, but the institute itself takes no institutional policy positions. The IZA research network is committed to the IZA Guiding Principles of Research Integrity.

The Institute for the Study of Labor (IZA) in Bonn is a local and virtual international research center and a place of communication between science, politics and business. IZA is an independent nonprofit organization supported by Deutsche Post Foundation. The center is associated with the University of Bonn and offers a stimulating research environment through its international network, workshops and conferences, data service, project support, research visits and doctoral program. IZA engages in (i) original and internationally competitive research in all fields of labor economics, (ii) development of policy concepts, and (iii) dissemination of research results and concepts to the interested public.
\end{abstract}

IZA Discussion Papers often represent preliminary work and are circulated to encourage discussion. Citation of such a paper should account for its provisional character. A revised version may be available directly from the author. 
IZA Discussion Paper No. 7275

March 2013

\section{ABSTRACT}

\section{The Transformation of Hunger Revisited}

We examine Trevon Logan's 2009 claim to have found low levels of nutrition among British worker's households in the late $19^{\text {th }}$ century. Using the same data, we conclude that Logan's estimates are thirty percent too low. Logan buttressed his estimates by claiming that the income elasticity of calories demand was unusually high among these households, relative to other estimates, reflecting great hunger. We find that the elasticity is high, but not outside the range observed in other data sets. We also warn against the simple assertion that a high elasticity implies hunger.

JEL Classification: I15, I32, N33

Keywords: nutrition, living standards, worker's households, late 19th century, Britain

Corresponding author:

Andrew Newell

Department of Economics

University of Sussex

Falmer, Brighton BN1 9SL

United Kingdom

E-mail: a.t.newell@sussex.ac.uk 


\section{Introduction}

Trevon Logan (2009) drew some remarkable conclusions based upon his analysis of the household expenditure data set collected in $1888 / 9$ by the United States Commissioner for Labor (Haines, 1979). Logan inferred that the households of American and British industrial workers in that period were nutritionally much worse off than, for example, rural households in the Indian province of Maharashtra during 1983. Further, he notes that his evidence is inconsistent with widely-accepted real income estimates, and implicitly entertains the possibility that these estimates are in need of revision.

These are puzzling findings. To put them into context, Angus Maddison's (2003) estimates for US and British per capita GDP in constant US dollars for 1890 are, respectively, 3.3 and 3.8 times higher than his estimate for India in 1983. Adjusting for the position of Maharashtra among the states of India would do little to reduce that huge difference. How could Logan's assertion on relative hunger be right? In this paper we concentrate on the comparison between Britain and India, but what we find may apply similarly to Logan's US findings.

Two findings underpin Logan's conclusions. First, as his Table 1 (ibid. p391) notes, Logan calculates average available daily calories per head at 1,646 for the United States 1,390 for Great Britain. He compares these with an estimate, made by Shankar Subramanian and Angus Deaton (1996) of 2,098 calories for the rural parts of Maharashtra province in SouthWest India 1983. This comparison between India and Britain is indeed surprising. As we show, the USCL data for Britain comprised of mostly skilled workers from some betterpaying industries. The claim that these workers consumed so little, only two-thirds of the 
rural Indian sample mean, is hard to believe, and would leave lower income British households very close to starvation. Logan's estimates are also inconsistent with a lot of other evidence from the same data sets, as we shall demonstrate, and are significantly below lan Gazeley and Sara Horrell's (2012) estimates of the nutritional attainment of rural workers in late nineteenth century Britain. Finally, we show how implausible Logan's findings appear when considered in relation to what is known of the relative heights of workers at that time.

Logan's second main finding is that the income elasticity of demand for calories is much higher for his US and GB samples than for the 1991/2 Bangladeshi sample he uses and those given by Subramanian and Deaton for Maharashtra. He also takes examples from John Strauss and Duncan Thomas (1995) that broadly support the view that the US and GB elasticities are unusually high. He interprets this elasticity as a measure of hunger. Even though Logan notes that when comparing elasticities across time and/or space, it is necessary to be alert to other possible causes of divergence, such as differences in relative prices and tastes, he maintains his hunger interpretation of the elasticity.

This paper calls into question Logan's first finding. For the British data we show that his calorie estimates are not replicable and are inconsistent with the available food price and calorie content data needed to estimate calories. We find that the diets of British workers at this time provided significantly greater energy levels. We also offer circumstantial evidence that is inconsistent with Logan's finding. On comparing the British USCL households to the Maharashtran households of Subramanian and Deaton's study, we find a much higher share of meat, a very expensive source of calories, in the British diet and a 
relatively low British share of food in total expenditure. Both these facts are absolutely inconsistent with the British in 1890 having lower levels of nutrition than those in the Maharashtran sample. Similarly we give anthropometric evidence on relative heights that also runs counter to Logan's finding.

On Logan's second finding, we find similar, though a little lower, elasticities of calories with respect to income or expenditure. As a check, we also estimate elasticities using Gazeley and Andrew Newell's (2011) 1904 Board of Trade data set and find similar results. However, we also find, by taking more examples of elasticities from studies of data from other countries, that these British results are not so unusual. Lastly we offer a simple alternative interpretation of these high elasticities. Note first that the income elasticity of calories is a weighted average of income elasticities of each food type. Further note that a sample in which highly income elastic meat is already a large part of the diet, compared with low income elastic staples will mechanically exhibit a high income elasticity of calories. We think this, rather than hunger, is the proximate cause of the high income elasticity in the USCL data.

In summary, our examination of the data leads us to conclude that both of Logan's major findings are incorrect. In the next section we discuss the US Commissioner of Labor data set. This is followed by a discussion of the conversion of the expenditure data to calorie estimates. After that we turn to a discussion of the income elasticity of calorie demand and the hunger interpretation of the elasticity. We conclude by placing this discussion in the broader context of the anthropometric evidence. 


\section{The USCL data}

Because of its value as a trans-national survey the 1890 and 1891 Sixth and Seventh Reports of the United States Commissioner of Labor (USCL) have been widely used and a number of attempts have been made to explore the likely biases of the dataset. Despite this scholarship, it remains the case that the method of implementation of the USCL survey is known only in the most general terms. We do know from Jeffery Williamson's biographic sketch of Carroll D. Wright (1840-1909), that he served in the Massachusetts Senate 1871-3 and that he was persuaded to take over the Massachusetts Bureau of Statistics of Labor in 1873. According to Williamson, Wright believed that 'voluntary circulars were an inadequate source of data' and that he developed and perfected advanced census techniques in a number of enquiries before the Sixth Annual Report in 1890 (Williamson, 1967, pp102-3). According to Michael Haines (1979, p.272), Wright was 'one of the United States' great empirical statisticians' and the Sixth and Seventh Reports were motivated by the McKinley Tariff question. To this end he was interested in data relating to the cost of production and the cost of living in nine industries in Europe and America (Williamson, 1967, p.105). These industries were all already protected in America and data was collected for twenty-four states in America and five European countries (Belgium France, Germany, Great Britain and Switzerland. Nearly one third of the international sample related to cotton textiles (31.8), while less than ten percent related to steel coke and iron ore (9.9 per cent). Further, 97.8 percent of the sample were male-headed households (Haines, 1979, p293-4).

The published reports themselves provide only the briefest of description of the way in which families were selected and family structure and expenditure information recorded. The Report merely states (in relation to Pig Iron): 
The Department has aimed to secure accounts from a representative number of the employees of the establishments......and also from those families whose surroundings and conditions made them representative of the whole body of employees in any particular establishment. The representative character, however, has been impaired in some measure by two features: first some families have not been willing to give the information desired; while second, other families, perfectly willing, have not been able to give reasonably exact accounts of their living expenses.'

The Report continues to highlight the fact that the families were asked to keep 'accounts for a year's living' and that the word family actually is used to describe households, as the family is meant as a 'totality - husband, wife, children, boarders, everybody that goes to make up the household. ${ }^{\text {ii }}$ It was not clear whether the sample was ever intended to be a random sample of families from the industries chosen. According to Lynn Hollen Lees (1980, p170), the head of the travelling commissioners claimed that employers supplied wage data and that 'home visits were made in the company of trusted local people to ask for information when regular accounts were not kept. Henry Higgs, a contemporary writing in 1893, according to Lees, guessed that the yearly totals were estimated from records kept over a much shorter period (ibid. p170). Lees suggests that the biases of the data include an over-representation of 'steadily employed' persons, unknown selection criteria for individuals and firms within industries (since region is not recorded it is impossible to investigate the extent of this bias).

A number of writers have attempted to investigate the extent to which the USCL survey was representative of workers in Britain in the 1890s. Lees examined the budgets of the sub- 
sample of 777 English households and found over half worked in the cotton and wool industries (52 percent) and that skilled workers 'predominate' in the sample. Lees thought that 'While the sample is clearly biased away from the unskilled, from the transient, the irregularly employed, and the youngest workers, it clearly reaches far beyond an aristocracy of labor'(ibid. p171). Further work on the biases of the USCL sample of British households was carried out by Tim Hatton et. al. (1994), who found that of the 956 workers they considered 263 were unskilled, 409 semi-skilled and 284 were skilled. However, this categorisation varied across industries such that 'unskilled workers form the dominant group in pig-iron and coke; semi-skilled workers the dominant group in cotton, wool and coal; and skilled workers the dominant group in steel, bar-iron and glass'(Hatton et. al. p440). Looking at average income by industry, therefore, gives a misleading impression of the hierarchy of high and low wage industries. This was further investigated by Horrell and Deborah Oxley (1999), who checked the average income figures recorded in the USCL budgets with data available for earnings in the industries and found that although the male earnings were 'in line with those for their occupations, the budgets oversample from the higher-paying occupations in each industry and the distribution of earnings for the whole sample thus falls into a higher range than that found for the industry as a whole'(ibid. p499).

Table 1 and Figure 1 illustrate Horrell and Oxley's point and show the extent to which the USCL likely oversamples heads of households with relatively high weekly earnings by comparing the distribution of recorded earnings in 1890-91 with the 1886 wage census.

[Table 1 about here] 
[Figure 1 about here]

There is compelling evidence, therefore, to suggest that the workers sampled in USCL were mostly in the higher-income part of the British wage distribution. One consequence of this is that it renders Logan's very low estimate of mean per capita calories in the USCL data highly implausible. For instance, the mean USCL wage of over 31 shillings is in the top $20 \%$ of the 1886 wage census distribution ${ }^{\mathrm{iii}}$.

\section{Calculating available calories in the USCL data}

In this section we investigate whether we can find something in Logan's method that accounts for his very low calories estimates. The details of Logan's method are given in his earlier paper (Logan, 2006). The food section of the USCL survey asks respondents to give itemised expenditure, which was then converted to in US dollars for just over twenty categories of food. For some food categories, the questionnaire also asked for food quantities, mostly for items which tended to be sold by a standard weight. The level of aggregation is quite high. From the point of view of calorie estimation, the two most problematical categories are those that aggregate, respectively, all fruits and all vegetables except potatoes. These are very small items in the budgets, however, and so are very unlikely sources of large errors in calorie estimation. 
To construct prices for deflating budget expenditures on each of the food categories, Logan took the average of the reported prices for foods in that category in the Aldrich Report (U.S. Senate Committee on Finance, 1892). The example he uses is the case of butter, for which two types, creamery and dairy, were recorded and these were averaged to create the butter price. The British prices in the Aldrich Report were collected from a limited number of stores in Leeds, Manchester, and Liverpool in June of 1889. Our averages from taken from the Aldrich Report are given in the first column of Table 2. What alternative prices are there? The USCL survey collected both expenditures and quantities purchased for some foods. We present the mean implicit deflator from USCL in the fourth column of Table 2. To reach a broader view of the validity of the Aldrich prices, we take prices from two alternative sources. The first and most important is British Parliamentary Papers, House of Commons Report on wholesale and retail prices for 1903 (BPP HC.321, 1903), which reports time series of retail prices for a large number of food types, often differentiated by quality and place of sale. Most of these are retail prices from London stores. We present these in Column 2 of Table 2.

For a number of important food types from 1893, the Labour Gazette regularly published prices from Co-op stores, which we present in Column 3 of Table 2. The fifth column of Table 2 gives our best set of prices, which are the USCL deflators where we have them with gaps filled on from the BPP HC.321 column. Bear in mind that bread, flour, butter, bacon, sugar, meat and potatoes are the key foodstuffs for nutrition. For three of these foodstuffs our 'mixed source' price is above our Aldrich price, for another three, the reverse is true and for the seventh, meat, the prices are identical. And, most importantly, for no energyimportant foodstuff is the price difference particularly large. As a consequence, we can 
assert that the estimated quantities - and hence our estimates of energy available from the diets - are not significantly affected by these price differences.

[Table 2 about here]

To convert from quantities to calories, Logan takes calorie values from Nutribase (2001). This source is encyclopaedic and gives nutrition data for a vast array of foods, for instance it offers over 350 types of bread alone, with wide variation in calorie estimates. This is problematic for replication purposes, as Logan does not provide details of the specific values he uses. Our approach is to sample from Nutribase by food category, and then use the mean calories from our sample plus, where possible, values that are plus or minus two standard deviations from the mean. These estimates are given as the first three columns of Table 3. The fourth column is from our preferred source of nutrition, commonly referred to as McCance and Widdowson (Paul and Southgate, 1979).

[Table 3 about here]

There are some major differences between these sources of energy values. Our mean Nutribase values are lower than the McCance and Widdowson values for meat, eggs and cheese and a lot higher for milk. In Table 4 we give our estimates of annual average household consumption of each food type. Column 1 reports average consumption (in Ibs) derived from reported quantities where available and otherwise from the expenditure data provided in the USCL survey reports deflated by the appropriate retail prices given in HC.301. 
Column 2 converts this to units of $100 \mathrm{~g}$ and in columns 3,4 and 5, these figures are used to derive daily household energy estimates using the Nutribase average, Nutribase low and McCance and Widdowson nutritional values. ${ }^{\text {iv }}$ Note that a significant proportion of food expenditure in the USCL survey is recorded as 'other expenditure', which requires us to make assumptions for the estimation of the energy value of these diets. We will return to this in a moment, but for those foods that are recorded separately, the importance of bread (baked and as flour) and butter in the diet is instantly visible in Table 4. Moreover, because the energy conversion factors of these items do not vary too much by source, the broad calorie story is the almost the same whichever conversion we use.

[Table 4 about here]

In Table 5 we present per capita daily calorie intakes estimated several ways. In column 1 and 2 we do not adjust for 'other food', while we make that adjustment in columns 3 and 4 . Column 1 of Table 5 is the sum of all foods reported in Table 4, using various nutritional conversions, divided by the mean household size. The energy values reported in column 3 inflate this total by food expenditure on other foods as a proportion of total food expenditure. This method treats these unspecified other foods as nutritionally equivalent to the average value of all specified foods. We do not know how Logan dealt with this problem, so we report the totals with and without this adjustment. In columns 2 and 4 of Table 5 we report our estimates direct from the household data, so these are the sample mean per capita daily calorie estimates, with standard errors attached. In principle the two numbers should be identical, but the mean calorie numbers in Table 4 and thus in Columns 1 and 3 of Table 5 are from all available observations, rather than observation where estimates for all 
foods are present, which is the case from columns 2 and 4 of Table 5 . Whichever method we use to calculate the nutritional value of the diets of British households in the USCL survey, we derive estimates of available energy per capita that are much higher than Logan. Our preferred estimate is that the energy available to the British urban households included in the USCL survey was around 2,000-2,200 kcal per capita per day, excluding calories from alcoholic drinks. This is about 30\% above Logan's estimate, from the same source, of less than $1,400 \mathrm{kcal}$ per capita per day. Adding energy from likely alcohol consumption, would probably raise this figure by about $400 \mathrm{kcal}$ (see Gazeley and Newell, 2012, p17). We note that our preferred estimate also is similar to Gazeley and Horrell's recent findings for the energy available to agricultural labourer's households of 2,153 kcal per capita per day in 1893-4, though this figure already includes energy from alcohol(Gazeley and Horrell, 2012,

p12). After a fairly exhaustive re-working, we conclude that some large errors were made in Logan's calculations. And these errors led him to some conclusions that are not supportable.

[Table 5 about here]

\section{Income/ expenditure calorie elasticities and hunger}

To investigate Logan's claim of a high income/expenditure elasticity of calorie demand, we first replicate Logan's basic OLS regression from Table 2 of his 2009 paper for Britain. The equation estimated is

$\ln ($ calories per capita $)=$ $\alpha_{0}+\alpha_{1} \ln ($ income per capita $)+$ family structure controls + error, 
In many studies income per capita is replaced by total expenditure per capita, for reasons of data availability. In the first two rows of Table 6 we report Logan's and our income and expenditure elasticities. Note first the estimated income elasticities are uniformly lower than the expenditure elasticities, a fact that holds more-or-less throughout the literature. Secondly, note that our estimate in row 2, based on calorie estimates from McCance and Widdowson is about $15 \%$ smaller than Logan's. For comparison, in the third row of Table 6 we report the results of re-estimating using our version of the Nutribase calorie conversion, but, again, this makes little difference. As a further comparison we estimate almost the same relationship using a Board of Trade sample of households from 1904 (see Gazeley and Newell, 2011). The results are very similar to our findings on the USCL data. Subramanian and Deaton's (1996) results are added in the last row, as these are key comparators in Logan's argument over the 'hunger' interpretation of his estimated elasticities. We conclude from this table that although Logan's estimates may be biased upward relative to ours by his calorie conversion, his substantial point about high-seeming elasticities is only moderated a little by choice of calorie conversion.

[Table 6 about here]

There is more evidence on calorie elasticities that can be brought bear, however. In a recent paper, Kolawoli Ogundari and Awudu Abdulai (2012) perform a meta-analysis of studies of the calorie-income elasticity. The range of elasticities they find is from almost zero to just under unity. 22 out of their 99 reported elasticities are over 0.5 in magnitude. Among these are estimates for Brazil, India, Kenya, the Philippines, Rwanda, Tanzania, Uganda and Vietnam. These findings suggest strongly that the USCL elasticities are within 
the spectrum of estimated elasticities. This finding is further evidence against the validity of Logan's claim to have found some very hungry people in late Victorian Britain.

[Table 7 about here]

Digging deeper into Ogandari and Abdulai's data we recalculate the mean elasticity omitting Logan's own US and GB estimates, and confining the sample to those 57 elasticities published in internationally-recognised journals. In that case, the mean elasticity is 0.35 with a standard error of 0.22 . In this perspective, Logan's income elasticity estimate for Britain of 0.50 , though in the higher range, is not remarkably high.

But it is Logan's interpretation of this elasticity, as a positive indicator of hunger than can be used to compare samples over space and time, that is most open to question. Let us again make a comparison between Britain in 1890 and Maharashtra in the early 1980s. Logan suggests that because of this high estimated elasticity for Britain, the households of some of the better-paid British workers around 1890 were a lot hungrier than rural families in Maharashtra in the early 1980s. There are two very telling statistics from USCL data and the tables in Subramanian and Deaton which weigh heavily against Logan's interpretation.

Firstly, in both the USCL and the Maharashtra samples, the price of calories purchased in the form of meat was around ten times that of calories purchased in the form of cereals. ${ }^{v}$ Among the Maharastran households, expenditure on meat was on average about $5 \%$ of total food spending (Subramanian and Deaton, 1996, Table 1). In the USCL sample, by contrast, the share of meat expenditure was more than five times larger on average, at 25.5\%. Making any reasonable allowance for cultural differences, it is very hard to believe that households with such low levels of available calories as Logan estimates would 
deliberately make themselves even more hungry by allocating so much of their budget to this most expensive form of energy.

The second statistic that weighs against the 'hunger' interpretation of the elasticity is the food share. Subramanian and Deaton give the mean food share on Maharashtra at $67 \%$; whereas the average food share in the USCL British data is $50 \%$, and the Marahashtran mean food share of $67 \%$ lies above the $95^{\text {th }}$ percentile of the British sample. The food share is very reliable index of economic well-being with a long history and it is unlikely that urban households surviving on very few calories would deliberately spend so little on food.

What alternative reasons might one put forward for a high income elasticity of calories in Britain (and the USA) in 1888/9? Here is an argument that suggests a different cause. Estimates of purchased calories are weighted sums of food quantities. It well known that the income elasticities of foods vary. Some, meat for instance, are regularly estimated to have higher income elasticities to others, bread and cereals, for instance. The income elasticity of a weighted sum of foods, each with different income elasticities, can easily be demonstrated to be a weighted sum of the income elasticities of the individual foods. ${ }^{\text {vi }}$ This has the implication that the estimated elasticity will be higher, ceteris paribus, the greater the importance income-elastic foods, such as meat, in the diet. We find, for instance, in the British USCL data, income elasticities of 0.50 (s.e. 0.04) for meat and 0.12 (s.e. 0.16) for bread and flour. As a consequence, though the hunger interpretation of the income elasticity of calorie demand is attractive, it is by no means the only possibility.

\section{Conclusions}


In this paper we contest Logan's (2009) claims (a) that the calories intakes of British worker's families in 1890 were very low and (b) that the impact of extra income on calorie demand was very high due to hunger. Firstly we find that Logan substantially underestimated the available calories for these families by about 30 percent. This fact alone undermines both of Logan's claims. Secondly, the British 1890 income elasticities do not look so much like outliers when a fuller range of studies is used for comparison. Thirdly, in comparison with Subramanian and Deaton's estimates for Maharashtra in the early 1980s, the average share of meat in the diet is very high among the British households and the average share of food in total expenditure is relatively low, both of which point to the Indian sample being relatively hungrier. Fourthly, we demonstrate that the 'hunger' interpretation of the income elasticity of calories does not hold unambiguously across samples from different cultures. It is very possible that, within a particular culture, it may be that the income elasticity of calories rises with hunger, but across cultures other factors, such as the balance of the diet, are at work. Fifthly, anthropometric historians might ask the question, if late nineteenth British skilled industrial workers were so hungry, how come they were so tall? For the last quarter of the nineteenth century, Roderick Floud et al $(2012, \mathrm{P} 69)$ provide an estimate of male adult height of $168 \mathrm{~cm}$. This compares with estimates of Bangladeshi adult male height for the late $1980 \mathrm{~s}$ of $163.9 \mathrm{~cm}$ and Indian male height of $163.4 \mathrm{~cm} .{ }^{\text {vii }}$

\section{References}


British Parliamentary Papers (1903) Return to an order of the Honourable the House of Commons, dated 6th August, 1903:--for "report on wholesale and retail prices in the United Kingdom in 1902, with comparative statistical tables for a series of years".(HC.321)

British Parliamentary Papers (1926) $18^{\text {th }}$ Abstract of Labour Statistics 'retail prices and the cost of living' Board of Trade, Labour Gazette August 1893

Gazeley, Ian and Horrell, Sara 'Nutrition in the English agricultural labourer's household over the course of the long nineteenth century' Economic History Review. Early on-line December 2012 DOI: 10.1111/j.1468-0289.2012.00672.x

Gazeley, Ian and Newell, Andrew 'Poverty in Britain in 1904: An Early Social Survey Rediscovered'. Economic History Review, 64 (1). pp. 52-71.

Gazeley, Ian and Newell, Andrew 'Urban Working Class Food Consumption and Nutrition in Britain in 1904' IZA DP No. 6988, November 2012.

Floud, Roderick, Robert W Fogel, Bernard Harris, and Sok Chul Hong, The Changing Body, Cambridge, (2012)

Haines, Michael R. "Industrial Work and the Family Life Cycle." Research in Economic History 4 (1979): 289-356.

Hatton, Timothy J. \& George R. Boyer \& Roy E. Bailey, "The Union Wage Effect in Late Nineteenth Century Britain," Economica vol. 61(244), pages 435-56, November.

Horrell, Sara and Deborah Oxley (1999) Crust or Crumb: Intra-household resource allocation and male breadwinning in late Victorian Britain.' Economic History Review

IAEA 'Compilation of anatomical, physiological and metabolic characteristics for a reference Asian man' Vol 2 Country Reports 1988-1993, Vienna (1998)

Lees, Lynn Hollen (1980) 'Getting and Spending: The Family Budgets of English Industrial Workers in 1890' in Consciousness and Class Experiences in nineteenth century Europe, London, 1980.

Logan, Trevon D. (2006). Nutrition and Well-Being in the Late Nineteenth Century. The Journal of Economic History, 66 , pp 313-341 doi:10.1017/S0022050706000131

Logan, Trevon D. (2009) The Transformation of Hunger: The Demand for Calories Past and Present. The Journal of Economic History, 69 , pp. 388-408 doi:10.1017/\$0022050709000825 Maddison, Angus, (2003), The World Economy- Historical Statistics, OECD, Paris. Nutribase (2001) The Nutribase Complete Book for Food Counts. New York: Avery, 2001. 
Ogundari, K. and A. Abdulai. A meta-analysis of the response of calorie demand to income changes. Selected Paper for presentation at the International Association of Agricultural Economists (IAAE) Triennial Conference, Foz do Iguacu, Brazil, 18-24 August, 2012.

Paul, A..A., and Southgate, D.A.T., McCance and Widdowson's The Composition of Foods (HMSO 1979).

Prest, A.R (1954) Consumers' Expenditure in the United Kingdom, 1900-1919 (Cambridge)

Strauss, John, and Duncan Thomas. "Human Resources: Empirical Modelling of Household and Family Decisions." In by Jere Behrman and T. N. Srinivasan (eds.) Handbook of Development Economics, Amsterdam: Elsevier, 1995, pp 1885-2023.

Subramanian, Shankar, and Angus Deaton. "The Demand for Food and Calories." Journal of Political Economy 104, no. 1 (1996): 133-62.

U.S. Senate Committee on Finance (1892). "Retail Prices and Wages: A Report by Mr. Aldrich." U.S. Senate Report No. 986. Washington, DC: GPO, 1892.

Williamson, Jeffrey G (1967) "Consumer Behavior in the Nineteenth Century: Carroll D. Wright's Massachusetts Workers in 1875." Explorations in Entrepreneurial History 4, no. 2 (1967): 98-138. 
Table 1: Wage distributions from the 1886 wage census and the USCL heads of households.

\begin{tabular}{lcc}
\hline $\begin{array}{l}\text { Percentage of sample with } \\
\text { weekly wages as follows }\end{array}$ & $\begin{array}{c}\text { Adult men in the } 1886 \text { wages } \\
\text { census }\end{array}$ & $\begin{array}{c}\text { Heads of households in the } \\
\text { USCL British sample }\end{array}$ \\
\hline 15 Shillings or less & 2.6 & 1.3 \\
Over 15 to 20 shillings & 21.5 & 4.8 \\
Over 20 to 25 shillings & 33.6 & 16.6 \\
Over 25 to 30 shillings & 24.2 & 22.8 \\
Over 30 to 35 shillings & 11.6 & 22.5 \\
Over 35 to 40 shillings & 4.2 & 12.4 \\
Over 40 shillings & 2.4 & 19.6 \\
\hline
\end{tabular}

Sources: calculated by authors from the 1890-91 United States Commissioner of Labor data and 1886 Wage Census British Parliamentary Papers 1893-94 [C.6889] 'Wages. General report on the wages of the manual labour classes in the United Kingdom, p.476'

Table 2: Comparison of US $\zeta$ prices used for conversion of expenditure to quantity

\begin{tabular}{l|c|c|c|c|c|}
\hline $\begin{array}{l}\text { Foodstuff (Ibs, } \\
\text { unless indicated) }\end{array}$ & $\begin{array}{c}\text { Mean } \\
\text { Aldrich } \\
\text { price }\end{array}$ & $\begin{array}{c}\text { BPP } \\
\text { HC.321 }\end{array}$ & $\begin{array}{c}\text { Mean Co- } \\
\text { op price }\end{array}$ & $\begin{array}{c}\text { Mean } \\
\text { USCL } \\
\text { deflator }\end{array}$ & $\begin{array}{c}\text { Mixed } \\
\text { source } \\
\text { price }\end{array}$ \\
\hline Bread & 3.50 & 3.11 & 2.59 & - & 3.11 \\
Butter & 24.3 & 28.0 & 27.5 & 25.2 & 25.2 \\
Cheese & 15.5 & 17.9 & 16.6 & - & 17.9 \\
Coffee & 29.7 & 40.1 & - & - & 40.1 \\
Eggs (per dozen) & 21.6 & 31.1 & - & 21.2 & 21.2 \\
Lard & 14.2 & 14.5 & - & 12.3 & 12.3 \\
Bacon & 16.0 & 15.0 & 18.7 & - & 15.0 \\
Fish & 13.7 & 8.3 & - & - & 8.3 \\
Fruit & 7.30 & 5.17 & - & - & 5.17 \\
Flour & 2.89 & 3.03 & 2.53 & - & 3.03 \\
Pork & 16.1 & 18.3 & - & 15.3 & 15.3 \\
Meat & 16.5 & 19.5 & - & - & 16.5 \\
Sugar & 4.80 & 4.15 & 5.71 & 4.90 & 4.90 \\
Tea & 44.2 & 59.1 & 50.6 & 52.4 & 52.4 \\
Vegetable & 11.2 & 2.03 & - & - & 2.03 \\
Condiments & 42.1 & 16.6 & - & - & 16.6 \\
Beef & 18.3 & 19.5 & - & - & 19.5 \\
Potatoes & 1.00 & 1.56 & 1.56 & 1.01 & 1.56 \\
Rice & 7.30 & 4.67 & - & - & 4.67 \\
Molasses & 1.85 & 6.74 & - & - & 6.74 \\
Milk (per pint) & - & 4.15 & 3.24 & - & 4.15 \\
\hline Sourcesofreal & & & & &
\end{tabular}

Sources of retail prices in Table 2:

(a) Column 1: U.S. Senate Committee on Finance. Retail Prices and Wages: A Report by Mr. Aldrich...

(b) Column 2:

Bread: BPP, HC.321 1890 large firm price (from Baker's Record), p.223.

Butter: HC.321 mean of Danish and Irish Butter London quarterly prices 1890, Firm A, p.285

Cheese: HC.321 weighted average of home-produced Cheddar (0.75) and imported American \& Canadian cheese (0.25); 1890 price Firm A, p.290 
Coffee: HC.321 mean of Mocha roasted \& ground, Costa Rica ground; London price 1890 Firm A, p.330

Eggs: HC.321, mean of quarterly prices for new laid eggs, 1890, Firm A , p.297

Lard: HC.321, mean of London price of Lard 1890, Firm (by block per lb) A and Firm D (per packet per lb), p.278

Fish: HC.321 commences 1898. Mean of quarterly London price for Haddock and whole Cod, Firm A, p.298. Note that the price of preserved Salmon was 7.5d/lb in 1891 ( Firm A, p.300)

Fruit: Prest average price 1900 of apples and pears, Table 32 p.60

Flour: HC.321 mean London 1890 price of household flour per 7lb, Firm A and Firm D, p.236-7

Pork: HC321 mean London 1890 price of 3 cuts (belly, chops, legs), Firm A, p.272

Meat(assumed to be mutton): HC.321 weighted average 1890 March and September price of 4 cuts of British Mutton (0.75) and 8 cuts of imported New Zealand Mutton(0.25), price Firm A, p.268-9

Sugar: HC.321 average of 1890 London prices for Demerara and granulated sugar Firm A and C, p.304 and 306 Tea: HC.324 average of 1890 London prices of 3 types of China and 3 types of Indian tea Firm A, p 325,

Vegetables: Prest average of 1900 price for cabbage, beans, peas, turnip, carrot, and onions. Table 29, p.52

Condiments: HC.321 average of 1890 London price of vinegar (Firm C per quart bottle) and ground black pepper per lb (Firm A), p.339 and p.340

Beef: HC.321 average of 1890 London prices (March and September) for 5 cuts of meat, Firm A p.260

Potatoes: HC.321 average of 1893-4 price for potatoes Firm A (no of Ibs per 12d), p.259

Rice: HC.321 average of 1890 London price per $2 \mathrm{lbs}$ for 5 types of rice (Firm A), p. 240

Molasses: HC.321 average 1890 London price per $2 \mathrm{lb}$ tin for golden syrup dark and light, Firm A p.308

Milk: HC.321 average 1890 London 'prevailing retail price', p.279

(c) Column 3: Co-operative store prices (average of 91 societies, 1893), The Labour Gazette, August 1893, p.88, for

Bread, Butter, Cheese, Bacon, Flour Sugar, Tea, Potatoes, Milk and Fresh Meat. The Gazette also lists the price of Margarine and Jams/Marmalade, which have not been used.

(d) Column 4 : Authors calculations from USCL data. 
Table 3: Calories available by food, per 100g, from Nutribase and McCance and Widdowson

\begin{tabular}{l|l|l|l|l}
\hline Food type & $\begin{array}{l}\text { Kcal Nutribase } \\
\text { average }\end{array}$ & $\begin{array}{l}\text { Kcal } \\
\text { Nutribase low }\end{array}$ & $\begin{array}{l}\text { Kcal } \\
\text { Nutribase high }\end{array}$ & $\begin{array}{l}\text { Kcal } \\
\text { McCance/Widdowson }\end{array}$ \\
\hline Beef & 260 & 115 & 368 & 216 \\
Pork & 233 & 233 & 506 & 280 \\
Mutton & 187 & 87 & 261 & 237 \\
Eggs & 49 & 49 & 49 & 147 \\
Lard & 814 & 814 & 814 & 891 \\
Butter & 716 & 716 & 716 & 740 \\
Tea & 0.3 & 0.3 & 1.2 & 1 \\
Coffee & 2.3 & 2.3 & 2.3 & 2 \\
Sugar & 351 & 351 & 351 & 394 \\
Molasses & 374 & 327 & 383 & 277 \\
Potatoes & 44.2 & 37.2 & 46.5 & 75 \\
Poultry & 224 & 90 & 326 & 65 \\
Fish & 77 & 68 & 78 & 65 \\
Milk & 239 & 239 & 490 & 65 \\
Flour & 334 & 334 & 334 & 350 \\
Bread & 250 & 224 & 250 & 245 \\
Rice & 299 & 222 & 342 & 361 \\
Cheese & 328 & 175 & 437 & 406 \\
Fruit & 56 & 15 & 77 & 1 \\
Vegetables & 38 & 21 & 49 & 2 \\
\hline
\end{tabular}

Table 4: average annual consumption per household

\begin{tabular}{|c|c|c|c|c|c|}
\hline $\begin{array}{l}\text { Food type } \\
\text { Period } \\
\text { Unit }\end{array}$ & $\begin{array}{l}\text { Average } \\
\text { consumption } \\
\text { Annual } \\
\text { lbs }\end{array}$ & $\begin{array}{l}\text { Mean } \\
\text { Consumption } \\
\text { Annual } \\
\mathrm{Kg} / 10\end{array}$ & $\begin{array}{l}\text { McCance/ } \\
\text { Widdowson } \\
\text { Daily } \\
\text { Kcal }\end{array}$ & $\begin{array}{l}\text { Nutribase } \\
\text { average } \\
\text { Daily } \\
\text { Kcal }\end{array}$ & $\begin{array}{l}\text { Nutribase low } \\
\text { Daily } \\
\text { Kcal }\end{array}$ \\
\hline Pork & 69.39 & 314.76 & 241.5 & 200.9 & 200.8 \\
\hline Meat-other & 413.55 & 1875.84 & 1218.0 & 961.0 & 446.9 \\
\hline Eggs & 40.71 & 184.68 & 74.4 & 24.8 & 24.8 \\
\hline Lard & 16.02 & 72.66 & 177.4 & 162.0 & 162.0 \\
\hline Butter & 112.00 & 508.03 & 1030.0 & 996.6 & 996.1 \\
\hline Tea & 26.56 & 120.48 & 0.3 & 0.1 & 0.1 \\
\hline Coffee & 8.17 & 37.05 & 0.2 & 0.2 & 0.2 \\
\hline Sugar & 198.48 & 900.29 & 971.8 & 865.8 & 865.4 \\
\hline Molasses & 6.26 & 28.41 & 21.6 & 29.1 & 25.4 \\
\hline Potatoes & 886.88 & 4022.87 & 826.6 & 487.2 & 409.8 \\
\hline Fish & 84.13 & 381.63 & 68.0 & 80.5 & 71.1 \\
\hline Milk & 361.62 & 1640.30 & 292.1 & 1074.1 & 1073.6 \\
\hline Flour & 890.37 & 4038.68 & 3872.7 & 3695.7 & 3694.0 \\
\hline Bread & 149.63 & 678.71 & 455.6 & 464.9 & 416.3 \\
\hline Rice & 2.20 & 9.97 & 9.9 & 8.2 & 6.1 \\
\hline Cheese & 3.18 & 14.43 & 16.1 & 13.0 & 6.9 \\
\hline Fruit & 12.58 & 57.06 & 0.2 & 8.7 & 2.3 \\
\hline Vegetable & 51.90 & 235.41 & 1.3 & 24.4 & 13.8 \\
\hline
\end{tabular}


Table 5: Mean daily calories available, per capita, estimates, all using Stone prices.

\begin{tabular}{l|l|l|l|l}
\hline $\begin{array}{l}\text { Kcal } \\
\text { conversions }\end{array}$ & $\begin{array}{l}\text { Sum of columns } \\
\text { of Table 4 }\end{array}$ & $\begin{array}{l}\text { Direct from the } \\
\text { data }\end{array}$ & $\begin{array}{l}\text { Sum of columns } \\
\text { of Table 4 }\end{array}$ & $\begin{array}{l}\text { Direct from the } \\
\text { data }\end{array}$ \\
\hline $\begin{array}{l}\text { Adjusted for } \\
\text { other foods? }\end{array}$ & No & No & Yes & Yes \\
$\begin{array}{l}\text { McCance and } \\
\text { Widowson }\end{array}$ & 1855 & $1968(19.3)$ & 2134 & $2245(23.1)$ \\
$\begin{array}{l}\text { Nutribase } \\
\text { Minimum } \\
\begin{array}{l}\text { Nutribase } \\
\text { mean }\end{array}\end{array}$ & 1683 & $1616(15.5)$ & 1936 & $1843(17.2)$ \\
\hline
\end{tabular}

Table 6: Calorie elasticity estimates from various cross-sections compared

\begin{tabular}{l|l|l|l}
\hline Calorie elasticity with respect to: & $\begin{array}{l}\text { Household } \\
\text { expenditure }\end{array}$ & $\begin{array}{l}\text { Household } \\
\text { income }\end{array}$ & Data set \\
\hline Logan (2009) & 0.674 & 0.50 & USCL GB \\
Authors & 0.571 & 0.298 & USCL GB, \\
Authors & 0.600 & 0.325 & USCL GB, Nutribase \\
Authors & 0.597 & 0.421 & Board of Trade 1904 \\
Subramanian and Deaton (1996) & 0.439 & 0.366 & Maharashtra, 1983 \\
\hline
\end{tabular}

Notes: All regressions also contain controls for family size, and the age and gender structure of the household and industry dummies. The only exception is the Board of Trade sample, in which children's genders are not recorded.

Table 7: Selected findings from Ogandari and Abdulai's (2012) meta-analysis of calorieincome studies

\begin{tabular}{l|l}
\hline Sample of studies (N) & Mean elasticity \\
\hline All estimates (99) & 0.312 \\
Cross section data only (72) & 0.3263 \\
Expenditure as an income proxy (64) & 0.383 \\
Actual income (35) & 0.183 \\
Instrumental variables (33) & 0.278 \\
\hline
\end{tabular}

Source: Ogundari and Abdulai (2012, Table 1, page 31) 


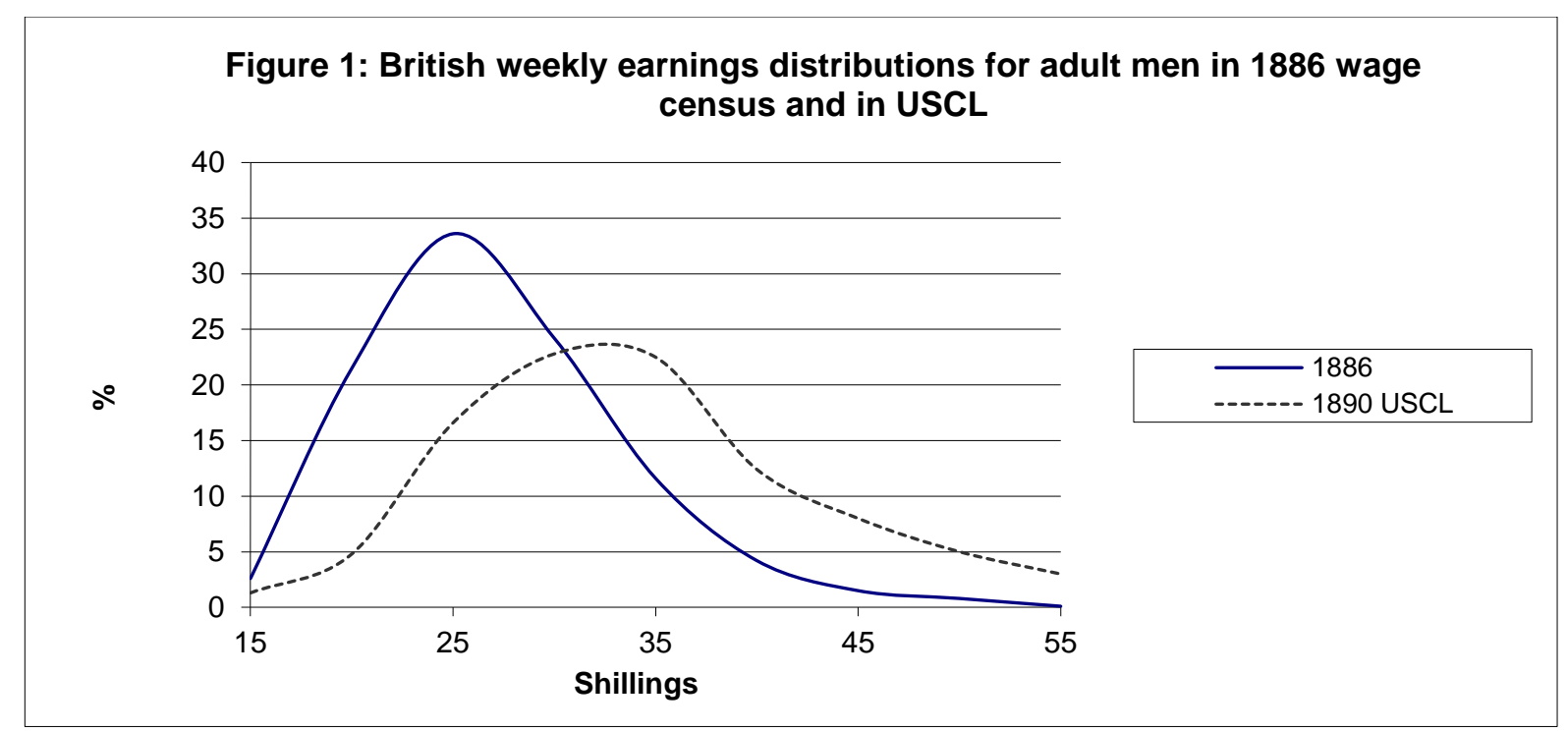

' Sixth Annual Report of the United States Commissioner of Labour pp 610-11. This same passage is quoted by Haines (1979) and Hatton and Bailey (1994)

ii ibid p.611

iii Price inflation was negligible 1886-1889/90.

iv Using the Aldrich prices made only very marginal differences when compared with HC.321, so we proceed using only this latter set of prices.

'Authors' own calculations and Subramanian and Deaton, 1996, Table 1.

${ }^{\mathrm{vi}}$ If calories $=\sum_{i} \beta_{i} F_{i}$, where $\beta_{l}$ is the calorie content of a unit of food $F_{i}$, each food has an income elasticity $\gamma_{l}$, then the elasticity of calories with respect to income is $\sum_{i} \gamma_{i} S h_{i}$, where $S_{i}$ is the share of food $i$ on total calories.

vii IAEA 'Compilation of anatomical, physiological and metabolic characteristics for a reference Asian man' Vol 2 Country Reports 1988-1993, Table 1, p.9 (Bangladesh), Table 1.p.48 (Indian), Vienna (1998) 